науково-дослідну роботу (проміжний). № держреєстраиії 0116U003202. Асканія-Нова: Біосферний заповідник «Асканія-Нова». С. 23-31.

Рубџов, А. Ф. (2017). Проект реконструкџії насаджень голонасінних рослин старого арборетуму. АсканіяНова, 19 с.

Рубџов, А. Ф. (2018). Проект реконструкџії насаджень голонасінних рослин нового арборетуму. АсканіяНова, 35 с. 1 додаток.

Рубџов, А. ФD. (2019). Проект реконструкції насаджень покритонасінних рослин старого арборетуму. Асканія-Нова, 65 с. 1 додаток.

Рубцов, А. Ф. (2020). Проект реконструкџії насаджень покритонасінних рослин нового арборетуму. Асканія-Нова, 72 с. 1 додаток.

Рубџов, А. Ф., Гавриленко, Н.О (2001). Ретроспективний аналіз структурних змін деревостанів старої частини дендропарку «Асканія-Нова». Вісті Біосферного заповідника «Асканія-Нова». Т. З. С. 29-37.

Рубџов, А. Ф., Гавриленко, Н. О. (2016). Зимостійкість деревних інтродуџентів дендрологічного парку «Асканія-Нова». Вісті Біосферного заповідника «Асканія-Нова». Т. 18. С. 177-197.

УДК 502.753:[712.253:58](477-25)

DOI 10.37555/2707-3114.1.2021.247359

\title{
Collection of rare woody plants species in M. M. Gryshko National Botanical garden
} of NAS of Ukraine

Gaponenko M. B., Ph. D., Gnatiuk A. M. Ph. D. M.M.

Gryshko National Botanical Garden of NAS of Ukraine, Kyiv, e-mail: gaponenko@nbg.kiev.ua, colchicum@i.ua

\section{Колекція рідкісних деревних рослин у Національному ботанічному саду імені М. М. Гришка НАН України}

Гапоненко М.Б, к.б.н., Гнатюк А. М. к.б.н.

Наџіональний ботанічний сад імені М. М. Гришко НАН України, Київ, е-mail: gaponenko@nbg.kiev.ua, colchicum@i.ua

\begin{abstract}
Preservation of rare plant species in nature (in situ) is an effective method of protection and maintenance of genetic diversity, but the preservation of plants ex situ is a necessary complement in modern conditions. In the M.M. Gryshko National Botanical Garden of NAS of Ukraine to preserve and replenish the collections of plants listed in the Red Book of Ukraine and other protection lists is defined as one of the strategic tasks of the institution. In total, the institution has collected 190 species of plants protected by the law "On the Red Book of Ukraine". The collection of rare and endangered tree and shrub plants is represented by 21 species, among which: Vulnerable - 9 (43\%), Rare - 7 (33\%), Endangered - 4 (14\%), Not Evaluated - 1 (5\%). This number of species and their representativeness is not sufficient for their successful protection ex situ. There is great prospects for expanding the collection to preserve species and spread the plants to other botanical gardens and arboretums of Ukraine.
\end{abstract}

Key words: Rare woody plants, introduction, collection, conservation, botanical gardens and arboretums.

Анотація. Збереження рідкісних видів рослин у природі (in situ) є ефективним методом охорони і підтримання генетичного різноманіття, проте збереження рослин еx situ є необхідним його доповненням в сучасних умовах. У НБС імені М.М. Гришка НАН України збереження і поповнення колекџій рослин, занесених до Червоної книги України та інших охоронних списків визначено як одне із стратегічних завдань установи. У џілому в установі зібрано 190 видів рослин, шо охороняються законом «Про Червону книгу України». Колекџія рідкісних і зникаючих деревних та кушових рослин НБС представлена 21 видом, серед яких: вразливі - 9 (43\%), рідкісні - 7 
(33\%), зникаючі - 4 (14\%), неоџінені - 1 (5\%). Џієї кількості видів та їх репрезентативності недостатньо для успішного захисту еx situ. Існують великі перспективи розширення колекџії для збереження видів та поширення рослин в інші ботанічні сади та дендропарки України.

Ключові слова: Рідкісні деревні рослини, інтродукџія, колекџія, збереження, ботанічні сади та дендропарки.

Introduction. Ukraine flora and microbiota contain more than 25,000 species of plants, fungi, mucous membranes, molds and lichens, including 4,523 natural species of vascular flora (1/3 of European flora), and together with the most important cultivated species - 5,088 species (Mosyakin \& Fedoronchuk, 1999; Los et al., 2014).

Indigenous dendroflora is the basis of forests, parks, street planting and plays a huge role in creating conditions for the existence and maintenance of biodiversity as a whole. Woody plants (trees, shrubs, bushes, and semi-shrubs) in the flora of Ukraine consist of 354 species (7, 83\%) (Zaverukha, 1985; Dendroflora of Ukraine, 2002, 2005). The most common indigenous edificators and generators of forest cenoses in Ukraine are Pinus sylvestris L., Quercus robur L., Fagus sylvatica L., Picea abies L., Fraxinus excelior L., Betula pendula Roth, Larix decidua Mill., Betula pubescens Ehrh, Quercus petraea L., Alnus glutinosa (L.) Gaertn, Carpinus betulus L., Acer platanoides L., Tilia cordata L., Abies alba Mill., Acer pseudoplatanus L., Ulmus laevis Pall., and their varieties. The problem of biodiversity conservation is very important for Ukraine, because its territory is under constant anthropogenic and technogenic pressure. Recently, the number of populations of many indigenous species has decreased significantly, and a large number of them have moved to the category of rare.

According to the order of the Ministry of Ecology and Natural Resources of Ukraine № 312 of 17.06.2009 "On approval of lists of species of plants and fungi included in the Red Book of Ukraine", there are 826 species, including 611 species of vascular plants. This book describes rare and disappearing plant species that require a special protection of their habitats and steps to be taken for their conservation and reproduction. The Red Book of Ukraine (2009) lists 51 species of woody plants; including 11 species from the European Red List and 5 species from the IUCN red list. Angiosperms make up 3.1\% of the total number of species of flora in Ukraine and almost $80 \%$ of species need partial or complete protection (Sobko \& Gaponenko, 1996), 7 species of plants are included in the Red Book of Ukraine (2009). On the territory of Ukraine 12 endemic species of trees and bushes that grow in a nature are protected and listed in to Red Book of Ukraine: Betula borysthenica Klokov, B. Klokovii Zaverucha, Cerasus klokovii Sobko, Chamaecytisus blockianus (Pawł.) Klásk., Chamaecytisus paczoskii (V. Krecz.) Klásk., Crataegus pojarkovae Kossych., Daphne sophia Kalen., Daphne taurica Kotov, Larix polonica Racib., Pinus stankewiczii (Sukacz.) Fomin, Rosa czackiana Besser. Woody plants listed in the Red Book of Ukraine are uncommon in culture and are practically not used in landscaping or in the creation of forest crops.

Preservation of rare plant species in nature (in situ) is an effective method of protection and maintenance of genetic diversity, but the protection of plants ex situ is a necessary complement in modern conditions. The importance of biodiversity conservation by ex situ methods is emphasized, in particular, in the "Global Strategy for Plant Conservation" (Global strategy..., 2002). Relevant work is carried out in botanical gardens of different countries and the basis of this activity is a number of policy documents of various levels, including the Convention on Biological Diversity (1992), International Agenda for Botanic Gardens in Conservation (2000), etc. An integral part of the overall strategy for the protection of flora is the preservation of its objects in ex situ conditions, including the cultivation of rare and endangered species in botanical gardens and arboretums.

Biodiversity loss is one of the major societal problems, so botanical gardens need to develop their collections, including the rare and endangered flora of Ukraine, to contribute to the conservation of biodiversity. Botanical gardens around the world are important for the tasks of studying and preserving plant diversity, as well as for the environmental education of the citizens, and for raising awareness among all sections of society about the importance of plants in human life (International Agenda, 2000). Botanic Gardens Conservation International (BGCI) has defined botanic gardens as: «institutions holding documented collections of living plants for the purposes of scientific research, conservation, display and education». The Botanical Gardens of Ukraine are the main regional organizations involved in the study, formation and maintenance of collection funds and conservation of natural flora in culture.

Material and Methods. The research was conducted on the basis of a collection of woody plants in the M. M. Gryshko National Botanical Garden of NAS of Ukraine in 2020-2021. Research methods are stationary 
(introductory) and in-house (data processing). Plants were identified by "Keys to higher plants of Ukraine” (1987), the names of taxa are presented accordingly to the Red Book of Ukraine (2009).

Results and Discussion. The M. M. Gryshko National Botanical Garden of National Academy of Sciences of Ukraine (NBG) has gathered collections of plants numbering more than 16,000 taxa. Keeping and updating collections of plants listed in the Red Book of Ukraine and other "red" lists ex situ is identified as one of the strategic objectives of the institution. In total, the institution has collected 190 species of plants protected by the law "On the Red Book of Ukraine".

The M. M. Gryshko National Botanical Garden of the NAS of Ukraine (NBG) plays an important role as an ecological centre of education and as the largest regional gene bank of plants, in particular the rare woody plants of the natural flora of Ukraine. In 1970 the "Rare plants of Ukrainian flora" plot was founded in NBG. Now the main part of the plot covers an area of 1.05 ha. (Gaponenko et al, 2012). In addition to herbaceous rare plant species, the collection also contains trees and shrubs. Quercus petraea (Matt.) Liebl., Larix polonica (Raciborski \& Wóycicki) Domin, Syringa josikaea J. Jacq. ex Rchb.), Staphylea pinnata L., Taxus baccata L, Cerasus klokovii Sobko, Corylus avellana L. were the first to be planted on this plot.

Within the plot, other trees were planted to create a microclimate for growing herbaceous plants. Pinus nigra Arnold, P. sylvestris L., Picea abies (L.) H. Karst., Fagus sylvatica L., Quercus robur L., Betula pendula Roth., Corylus colurna L., Taxodium distichum (L.) Rich, these are the plants that are growing on the plot since 70-80 years of the last century. Now these trees create the conditions for the growth of herbaceous plants and shrubs such as Daphne sophia Kalen., D. taurica Kotov, D. cneorum L., D. mezereum L, Euonymus nana M. Bieb. Saplings and seeds of Ukrainian flora plants were taken mainly from natural habitats and another botanical gardens of Ukraine.

Rare plants are in the collections of almost all departments of the NBG, but tree species are concentrated mainly in the departments of Dendrology and Natural flora (include a special plot "Rare plants of Ukrainian flora"). There are 5 Gymnospermae and 16 Angiospermae species from the Red Book of Ukraine (2009) woody plants are represented in the culture of the NBG (table).

Conclusions. Among the 51 species of woody plants listed in the Red Book of Ukraine, 11 species are included in the European Red List and 5 species belong to the IUCN list.

The collection of rare and endangered trees and shrubs of the M. M. Gryshko National Botanical Garden of NAS of Ukraine is represented by 21 species, among which: Vulnerable - 9 (43\%), Rare - 7 (33\%), Endangered - 4 (19\%), Not Evaluated - 1 (5\%).

There are 5 Gymnospermae out of 7 species from the Red Book of Ukraine in the culture of the NBG. Angiosperms dicotyledonous woody plants in the Red Book are represented by 44 species, in the collection of the NBG - 16 species. This number of species and their representativeness is not sufficient for their successful protection ex situ. There is great prospects for expanding the collection to preserve species and spread the plants to other botanical gardens and arboretums of Ukraine.

Table. The rare woody plants listed in the Red Book of Ukraine (2009) in the collection of the M. M. Gryshko National Botanical Garden

\begin{tabular}{|l|l|l|l|}
\hline \multicolumn{1}{|c|}{ Family } & \multicolumn{1}{|c|}{ Genus } & \multicolumn{1}{c|}{ Species } & \multicolumn{1}{c|}{$\begin{array}{c}\text { Conservation status } \\
\text { in Ukraine }\end{array}$} \\
\hline \multirow{2}{*}{ Cupressaceae Gray } & \multirow{2}{*}{ Juniperus L. } & Juniperus excelsa M. Bieb. & Vulnerable \\
\cline { 3 - 4 } & & Juniperus foetidissima Willd. & Rare \\
\hline \multirow{2}{*}{ Pinaceae Lindley } & Larix Mill. & Larix polonica Racib. & Endangered** \\
\cline { 2 - 5 } & Pinus L. & Pinus cembra L. & Vulnerable \\
\hline Taxaceae S. F. Gray & Taxus L. & Taxus baccata L. & Vulnerable \\
\hline Caprifoliaceae Juss. & Lonicera L. & Lonicera caerulea L. & Rare \\
\hline Celastraceae R. Br. & Euonymus L. & Euonymus nana Bieb. & Vulnerable \\
\hline
\end{tabular}




\begin{tabular}{|c|c|c|c|}
\hline 1 & 2 & 3 & 4 \\
\hline \multirow{4}{*}{ Fabaceae Lindl. } & \multirow{3}{*}{$\begin{array}{l}\text { Chamaecytisus } \\
\text { Link }\end{array}$} & Chamaecytisus graniticus (Rehmann) Rothm. & Vulnerable \\
\hline & & Chamaecytisus podolicus (Błocki) Klask. & Vulnerable \\
\hline & & Chamaecytisus rochelii (Wierzb.) Rothm. & Rare \\
\hline & Genistella Ortega & Genistella sagitalis L. & Rare \\
\hline \multirow{2}{*}{$\begin{array}{l}\text { Oleaceae Hoffmanns. } \\
\text { \& Link }\end{array}$} & Fraxinus L. & Fraxinus ornus L. & Rare \\
\hline & Syringa L. & Syringa josikaea J. Jacq. ex Rchb. & Vulnerable*,** \\
\hline Rhamnaceae Juss. & Rhamnus L. & Rhamnus tinctoria Waldst. et Kit. & Rare \\
\hline \multirow{3}{*}{ Rosaceae Juss. } & Cerasus L. & Cerasus klokovii Sobko & Vulnerable \\
\hline & Sorbus L. & Sorbus torminalis Crantz & Not Evaluated \\
\hline & Spiraea L. & Spiraea polonica Błocki & Endangered \\
\hline Staphyleaceae Martynov & Staphylea L. & Staphylea pinnata L. & Rare \\
\hline \multirow{3}{*}{ Thymelaeaceae Juss. } & \multirow{3}{*}{ Daphne L. } & Daphne cneorum L. & Vulnerable \\
\hline & & Daphne sophia Kalen. & Endangered $* * *$ \\
\hline & & Daphne taurica Kotov & Endangered* ${ }^{*}$ \\
\hline
\end{tabular}

\section{References}

Chopik, V.I. Rare and endangered plants and animals. - K.: Nauk. Dumka, 1988. P. 20-114. (in Ukrainian). Convention on Biological Diversity. (1992) Text and Annexes. Secretariat of the Convention on Biological Diversity/UNEP, Montreal, Canada: 34 pp.

Dendroflora of Ukraine. Wild and cultivated trees and shrubs. Angiosperms. Part I: reference book. [Kokhno M. A., Parkhomenko L. I., Zarubenko A. U. etc.]; for order. MA. Kohna. - Kyiv: Phytosocial center, 2002. 448 p. (in Ukrainian).

Dendroflora of Ukraine. Wild and cultivated trees and shrubs. Angiosperms. Part II: handbook. - [Kokhno M.A., Trofimenko N. M., Parkhomenko L. I. etc.]; for order. MA. Kohna and N. M. Trofimenko. - Kyiv: Phytosocial center, 2005. - 716 p. (in Ukrainian).

Fedoronchuk, M.M., Belemets, N.M., Volutsa, O.D. (2013) Rare species of the genus Spiraea L. (Rosaceae) of the Ukrainian flora and their conservation status. Ukr. Bot. J., 70(2): 164-167. (in Ukrainian).

Gaponenko, M.B., Lebeda, A.P., Alokhin, O.O., etc. (2011). Catalog of rare plants of botanical gardens and

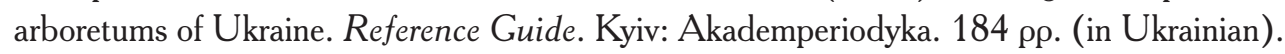

Gaponenko, M.B., Sobko, V.G., Gnatiuk, A.M., (2012) Rare species of the collection area "Rare plants of the flora of Ukraine" of the M. M. Gryshko National Botanical Garden of NAS of Ukraine. Problems of experimental botany and biotechnology. - Kyiv: Phytosocial Center. - P. 72-83. (in Ukrainian).

Green Book of Ukraine (2009) (Under the general editorship of the corresponding member of the NAS of Ukraine Ya. P. Didukh) - Kyiv: Alterpress. - 448 p. (in Ukrainian).

GSPC (2002). Global Strategy for Plant Conservation. Published by the Secretariat of the Convention on Biological Diversity. Available online at: www.cbd.int/gspc/

Keys to higher plants of Ukraine / Academy of Sciences of the Ukrainian SSR; Institute of Botany. N.P. Kholodny; ed. Yu. N. Prokudin and others. Kiev: Naukova Dumka, 1987. 548 p.

Los, S.A., Tereshchenko, L.I., Gayda, Yu.I., Ustimenko, P.M., Yatsyk, R.M., Chernyavsky, M.V., Neyko, I.S., Torosova, L.O., Dutka, M.M., Polakova, L.V., Sapiton, O.A., Grechanik, R.M., Fushilo, Ya. D., Sbitna, M.D., Shlonchak, G.A., Mitrochenko, V.V., Shlonchak, G.V., Samoday, V.P., Trofimenko, N.M., Voytuk, V.P., Volosyanchuk, R.T., Fennich, V.S., Grigor'eva, V.G., Voloshinova, N.O., Jurova, P.T. (2014). State of forest genetic resources in Ukraine. Kharkiv: Planeta-Print. - 138 p.

Mosyakin, S. L. \& Fedoronchuk, M. M., (1999) Vascular plants of Ukraine. A nomenclatural checklist, Kyiv. -345 p. 
Red Book of Ukraine. Flora. (2009) Ed. J. P. Didukh. - Kyiv: Globalkonsalting. - 900 p. (in Ukrainian).

Sobko, V. G. (1973) A new species of cherry (Cerasus klokovii Sobko sp. nov.) from the granite outcropping of the South Bug area in Ukrajins\&apos; k. Bot. Žurn, 30.- P. 663-665. (in Ukrainian).

Sobko, V.G., Gaponenko, M.B. (1996) Introduction of rare and endangered plants of the flora of Ukraine. Kyiv: Naukova Dumka, 284 p. (in Ukrainian).

Wyse Jackson, P.S., Sutherland, L.A., (2000). International Agenda for Botanic Gardens in Conservation. Botanic Gardens Conservation International, UK.

Zaverukha, B.V. (1985). Flora of Volyno-Podolia and its genesis. Academy of Sciences USSR, N. G. Kholodny In-t of botany. Kyiv: Nauk. Dumka, - 190 p. (in Russian).

УДК 581.9

DOI 10.37555/2707-3114.1.2021.247360

\section{Аосвід інтродукції Hydrangea petiolaris Siebold \& Zucc. у Національному дендрологічному парку «Софіївка» НАН України}

Гончарова А. В., Коджебаш А. П.

Наџіональний дендрологічний парк «Софіївка» НАН України, Черкаська обл., м. Умань, Україна, e-mail: ukrcargo@ukr.net

\section{Introduction experience Hydrangea petiolaris Siebold \& Zucc. in the National Dendrological Park "Sofiyivka"}

Goncharova A. V., Kodzhebash A.P.

National Dendrological Park «Sofiyivka» NAS of Ukraine, Uman, Ukraine, e-mail: ukrcargo@ukr.net

Анотація. Наведено дані шодо природного ареалу та історії інтродукџії Hydrangea petiolaris Siebold \& Zucc., а також результати спостережень за інтродукованими рослинами у Наџіональному дендрологічному парку «Софіївка» НАН України впродовж 2014-2020 років. Узагальнено результати інвентаризаџійних досліджень H. petiolaris в дендрологічних парках та ботанічних садах України. Виявлено, шо більшість із них успішно адаптувалися до чинників нового середовиша, добре ростуть і розвиваються в ботанічних садах і дендропарках. Використання культивованих особин $H$. petiolaris сприятиме покрашенню стану наявних насаджень, підвищенню декоративності і загалом покрашенню естетичного та санітарно-гігієнічного стану зелених насаджень загального користування населених пунктів Правобережного Лісостепу України. Застосований нами метод інтегральної числової оџінки життєздатності та перспективності інтродукџії деревних і кущових рослин на основі візуальних спостережень за П. І. Лапіним, С. В. Сіднєвою (1973) засвідчив перспективність інтродукџї H. petiolaris в умови Правобережного Лісостепу України.

Ключові слова. Hydrangea petiolaris, дендросозофіт, походження, інтродукџія, розвиток

Abstract. The information on the natural habitat and the history of Hydrangea petiolaris Siebold \& Zucc. The results of inventory researches of $H$. petiolaris in dendrological parks and botanical gardens of Ukraine are generalized. It was found that most of them successfully adapt to the factors of the new environment, grow well and develop in botanical gardens and arboretums. The use of cultivated individuals of $H$. petiolaris will help to improve the condition of existing plantations, increase decorativeness and generally improve the aesthetic and sanitary and hygienic condition of green areas of public use in the settlements of the Right Bank Forest-Steppe of Ukraine. We used the method of integrated numerical assessment of viability and prospects for the introduction of woody and shrubby plants on the basis of visual observations 